\title{
Genetic parameters of age at first calving, weight gain, and visual scores in Nelore heifers
}

\author{
Luís Afonso Marques Claus ${ }^{1}$, Celso Koetz Júnior ${ }^{2 *}$, Vanerlei Mozaquatro Roso ${ }^{3}$, Marcelo \\ Henrique Favaro Borges ${ }^{2}$, Júlio Otávio Jardim Barcellos ${ }^{4}$, Edson Luis de Azambuja Ribeiro ${ }^{5}$
}

\author{
${ }^{1}$ Universidade Estadual de Londrina, Programa de Pós-graduação em Ciência Animal, Londrina, PR, Brazil. \\ 2 Universidade Norte do Paraná, Arapongas, PR, Brazil. \\ ${ }^{3}$ GenSys Consultores Associados S/S, Porto Alegre, RS, Brazil. \\ ${ }^{4}$ Universidade Federal do Rio Grande do Sul, Faculdade de Agronomia, Departamento de Zootecnia, RS, Brazil. \\ ${ }^{5}$ Universidade Estadual de Londrina, Departamento de Zootecnia, Londrina, PR, Brazil.
}

\begin{abstract}
This study aimed at estimating the heritability of age at first calving and of performance traits included in the selection index and the genetic correlations between age at first calving and these performance traits. Data were extracted from the Conexão Delta G database and only data from herds in which heifers were bred younger than 24 months of age were used, resulting in a file with 331,310 evaluated animals. The following traits were included in the analyses: age at first calving, birth to weaning gain, post-weaning weight gain, visual scores of conformation, precocity, and muscling evaluated at weaning and in yearling heifers. Covariance components were obtained by bi-character analyses between traits. An alternative age at first calving was also taken into account, in which all heifers were used, including those that were mated and did not calve. Covariance components and estimates of the effects included in the model were obtained using the software program DMU. Heritability estimates were 0.11 and 0.13 for age at first calving and alternative age at first calving, 0.38 for birth to weaning gain, and 0.13 for post-weaning weight gain. Visual score estimates ranged between 0.16 and 0.18 at weaning and 0.19 and 0.29 in yearlings. Genetic correlation estimates of the traits were low, but in the desirable direction. Selection for birth to weaning gain and visual scores does not have a negative effect on age at first calving or alternative age at first calving.
\end{abstract}

Key Words: beef cattle, breeding, heritability

\section{Introduction}

Age at first calving (AFC) in cattle determines reproduction precocity of heifers, that is, how early they are able to conceive, gestate, and calve. Although this trait is easy to collect when calving date is known, AFC expression depends on the breeding season when the heifer was born and when it was mated. In tropical regions, late age at first calving is one of the main negative factors that influence beef production. Reducing age at first calving increases profitability (Nunez-Domingues et al., 1991). Although estimates of heritability for reproductive traits are low (Dias et al., 2004; Azevêdo et al., 2006), age at first calving of Nelore heifers is highly variable, ranging from

Received: June 27, 2016

Accepted: January 26, 2017

*Corresponding author: celsokoetzjr@yahoo.com.br

http://dx.doi.org/10.1590/S1806-92902017000400005

How to cite: Claus, L. A. M.; Koetz Júnior, C.; Roso, V. M.; Borges, M. H. F.; Barcellos, J. O. J. and Ribeiro, E. L. A. 2017. Genetic parameters of age at first calving, weight gain, and visual scores in Nelore heifers. Revista Brasileira de Zootecnia 46(4):303-308

Copyright (C) 2017 Sociedade Brasileira de Zootecnia. This is an Open Access article distributed under the terms of the Creative Commons Attribution License (http://creativecommons.org/licenses/by/4.0/), which permits unrestricted use, distribution, and reproduction in any medium, provided the original work is properly cited.
47 (Biffani et al., 2000) to 35 months (Dias et al., 2004), suggesting that it can be reduced.

To improve carcass characteristics in Nellore cattle, the use of visual scores has been used (Forni et al., 2007; Koury Filho et al., 2009, 2010). The use of these visual scores has the advantage of being performed on live animals and at early ages.

Selection for unique characteristics may be accompanied by correlated responses in other characteristics. However, these correlated answers are not always in the desired direction. This can be seen when the selection for weight gains and carcass characteristics can result in larger-sized animals. Consequently, the size of the females may also increase, resulting in higher nutritional requirements, which in turn may negatively affect the reproductive performance of females kept on pasture. To try to solve these problems, the use of selection indices are fundamental (Hazel et al., 1994).

Whenever using selection indexes, it is essential to evaluate whether the results of the selection are in accordance with what was predicted, as well as to make the necessary adjustments. In this way, it is very important to monitor the genetic changes that may have occurred. Therefore, the objectives of the present study were to estimate the heritability of age at first calving and 
production traits included in the Conexão Delta G selection index and to estimate the genetic correlations between age at first calving and these production traits.

\section{Material and Methods}

Data of Nelore cattle were extracted from the database of Conexão Delta G. Only data from commercial herds that breed their heifers younger than 24 months of age were included, resulting in a file with 331,310 animals born between 1984 and 2008 in herds of eight different states of Brazil. The pedigree file contained 387,877 animals.

The following traits were included in the analyses: age at first calving, birth to weaning weight gain, post-weaning weight gain, visuals scores of conformation at weaning and at 18 months, precocity at weaning and at 18 months, muscling at weaning and at 18 months, and final index.

An alternative age at first calving ( $\mathrm{AFCg}$ ) was also evaluated, in which all heifers, including those that were mated and did not calve, were taken into account. The $\mathrm{AFCg}$ of non-calving heifers was computed as if heifers calved 60 days after the last heifer of the same management group had calved (Bormann and Wilson, 2010).

Animals were individually scored for conformation, precocity, and muscling relative to their management group in a scale of 1 to 5, as described by Severo (1994).

The production traits were pre-adjusted for age, dam age, and Julian birth date using correction factors generated by Conexão Delta G.

Age at first calving and $\mathrm{AFCg}$ contemporary groups were formed by farm, year of birth, calving season, and management group. Contemporary groups of production traits were formed by farm, year and season of birth, sex, management group, and Julian date of the evaluation.

Animals were evaluated and ranked according to an index, called final index. Percentage weightings applied on the standardized expected progeny differences of the traits included in the final index were: birth to weaning weight gain $(\mathrm{kg}), 25 \%$; conformation at weaning (1-5 score), 4\%; precocity at weaning (1-5 score), $8 \%$; muscling at weaning (1-5 score), $8 \%$; post-weaning weight gain $(\mathrm{kg}), 25 \%$; conformation at 18 months ( $1-5$ score), $4 \%$; precocity at 18 months (1-5 score), $8 \%$; muscling at 18 months (1-5 score), $8 \%$; and scrotal circumference $(\mathrm{cm}), 10 \%$.

Traits were analyzed using a bi-character animal model (Schaeffer, 2011), in which reproductive traits (AFC or $\mathrm{AFCg}$ ) were analyzed together with production traits (weight gains, visual scores, and final index).
The general model used, in matrix notation, is described as follows:

$$
\mathrm{Y}=\mathrm{X} \beta+\mathrm{Za}+\mathrm{Wm}+\mathrm{Sp}+\mathrm{e},
$$

in which $\mathrm{Y}=$ vector of phenotypic records; $\mathrm{X}=$ incidence matrix relating each observation to each fixed effect; $\beta=$ vector of fixed effects (contemporary groups); $Z=$ incidence matrix of direct additive genetic effects; $a=$ vector of direct additive genetic effects; $\mathrm{W}=$ incidence matrix of maternal additive genetic effects; $\mathrm{m}=$ vector of maternal additive genetic effects; $\mathrm{S}=$ incidence matrix of permanent environmental effects; $p=$ vector of permanent environmental effects; $\mathrm{e}=$ vector of random residuals. Assuming $\mathrm{E}[\mathrm{Y}]=\mathrm{X} \beta$ and $\mathrm{E}[\mathrm{a}]=\mathrm{E}[\mathrm{m}]=\mathrm{E}[\mathrm{p}]=\mathrm{E}[\mathrm{e}]=0$.

Maternal additive genetic effects and maternal permanent environmental effects were included only in the traits evaluated at weaning. In the final index analyses, only direct additive genetic effects were considered.

Covariance components were estimated by the method of restricted maximum likelihood. The DMU program (Madsen et al., 2006) was employed to obtain covariance components and the solutions of the effects included in the statistical model.

Direct $\left(\sigma_{\mathrm{a}}^{2}\right)$ and maternal $\left(\sigma_{\mathrm{m}}{ }^{2}\right)$ additive genetic variance estimates were expressed as ratios of the phenotypic variance $\left(\sigma_{\mathrm{t}}^{2}\right)$, as: $\sigma_{\mathrm{t}}^{2}=\sigma_{\mathrm{a}}^{2}+\sigma_{\mathrm{m}}^{2}+\sigma_{\mathrm{am}}+\sigma_{\mathrm{p}}^{2}+\sigma_{\mathrm{e}}^{2}$.

Direct and maternal heritabilities were calculated as: $\mathrm{h}_{\mathrm{a}}^{2}=\sigma_{\mathrm{a}}{ }^{2} / \sigma_{\mathrm{t}}{ }^{2}$ and $\mathrm{h}_{\mathrm{m}}{ }^{2}=\sigma_{\mathrm{m}}{ }^{2} / \sigma_{\mathrm{t}}{ }^{2}$, respectively.

The genetic correlations between direct additive effects of the pairs of traits analyzed together $\left(\mathrm{r}_{\mathrm{a} 12}\right)$ were calculated as $r_{a 12}=\sigma_{a 12} /\left(\sigma_{a 1} \sigma_{a 2}\right)$, in which $\sigma_{a 12}=$ genetic co-variance between direct additive effects of the pair of traits evaluated together, $\sigma_{\mathrm{a} 1}=$ direct additive genetic standard deviation of the first trait, and $\sigma_{\mathrm{a} 2}=$ direct additive genetic standard deviation of the second trait.

\section{Results}

Age at first calving and $\mathrm{AFCg}$ calculated means were 33.36 and 33.39 months, respectively (Table 1). The heritability estimates of the direct effect of the reproductive traits AFC and AFCg were both 0.11 at weaning (Table 2) and were higher at age of 18 months (0.13) (Table 3). When the second character was the final index, heritability for AFC and AFCg was 0.12 (Table 4).

Although the estimated heritability for AFC and AFCg was of low magnitude, the analysis of data of the bulls included in the selection program with more than 100 daughters evaluated (Figure 1) showed high variability in the percentage of daughters with AFC lower than 28 months 
of age, suggesting that AFC may be reduced by genetic selection if the best bulls for this trait are used.

The variability is also observed when AFC is standardized to expected progeny differences and bulls with more than 100 daughters were analyzed (Figure 2). In this particular case, the difference between best and worst bulls is close to 20 days and the use of best bulls could generate heifers with AFC 10 days earlier than average bull's daughter. The heritability estimate obtained for birth

Table 1 - Number of observations, means, standard deviations, and minimal and maximal values of weight gain, weaning and yearling visual scores, age at first calving (AFC and $\mathrm{AFCg}$ ), and final index

\begin{tabular}{|c|c|c|c|c|c|}
\hline Trait & $\begin{array}{l}\text { Number of } \\
\text { observations }\end{array}$ & Mean & SD & Minimum & Maximum \\
\hline $\mathrm{WG}^{1}(\mathrm{~kg})$ & 331.310 & 152.66 & 26.35 & 38.47 & 333.64 \\
\hline $\mathrm{WC}^{1}$ (score) & 278.068 & 3.40 & 1.11 & 0.30 & 7.18 \\
\hline $\mathrm{WP}^{1}$ (score) & 278.074 & 3.50 & 1.13 & 0.29 & 7.10 \\
\hline $\mathrm{WM}^{1}$ (score) & 278.072 & 3.31 & 1.15 & 0.25 & 6.95 \\
\hline $\mathrm{YG}^{2}(\mathrm{~kg})$ & 169.361 & 105.15 & 34.66 & 31.32 & 368.82 \\
\hline $\mathrm{YC}^{2}$ (score) & 184.769 & 3.60 & 1.08 & 0.13 & 8.15 \\
\hline $\mathrm{YP}^{2}$ (score) & 184.764 & 3.56 & 1.10 & 0.50 & 7.81 \\
\hline $\mathrm{YM}^{2}$ (score) & 184.726 & 3.34 & 1.12 & 0.17 & 8.19 \\
\hline AFC (days) & 42.813 & 1001.09 & 129.97 & 600.00 & 1598.00 \\
\hline AFCg (days) & 53.240 & 1001.89 & 132.11 & 600.00 & 1599.00 \\
\hline Final index (points) & 113.323 & 7.3734 & 5.11 & 0.19 & 33.35 \\
\hline \multicolumn{6}{|c|}{$\begin{array}{l}{ }^{1} \mathrm{WG} \text { - weight gain; WC - conformation; WP - precocity; and WM - muscling at } \\
\text { weaning. } \\
{ }^{2} \text { YG - weight gain; YC - conformation, YP - precocity; and YM - muscling at } \\
\text { eighteen months of age. } \\
\text { AFC - age at first calving; AFCg - alternative age at first calving, including heifers } \\
\text { that did not calve; SD - standard deviation. }\end{array}$} \\
\hline
\end{tabular}

to weaning weight gain was 0.18 and 0.19 for post-weaning weight gain.

Heritability estimates for the evaluated visual score traits ranged between low and intermediate, with the lowest value obtained at weaning for muscling (0.16) and the highest for precocity (0.18). The lowest heritability estimate obtained in yearlings was for weight gain (0.19) and the highest for precocity $(0.29)$.

Direct heritability estimates found for the visual score traits at weaning were $0.17,0.18$, and 0.16 , respectively for conformation, precocity, and muscling. Maternal heritability estimates found for the visual score traits at weaning were $0.07,0.06$, and 0.07 , respectively for conformation, precocity, and muscling.

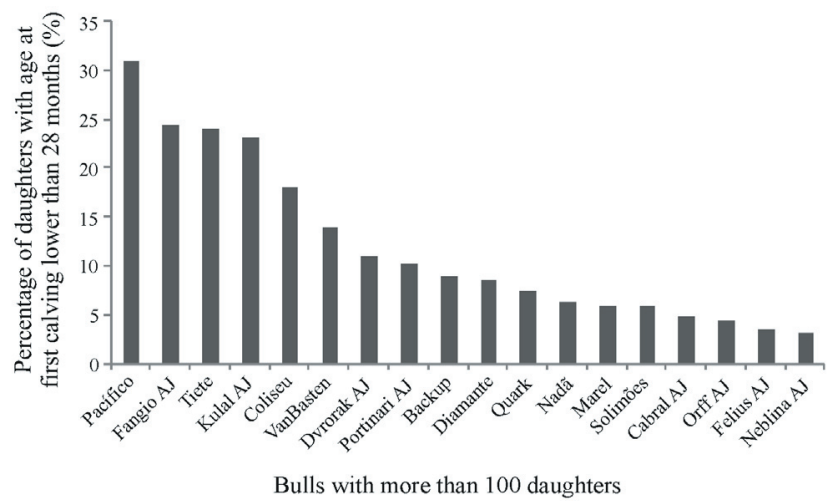

Figure 1 - Bulls with more than 100 daughters and percentage of daughters with age at first calving lower than 28 months.

Table 2 - Covariance component estimates and genetic parameters obtained with the bi-character analyses of the traits age at first calving (AFC) and age at first calving with the inclusion of heifers that did not calve (AFCg) with weight gain (WG), conformation (WC), precocity (WP), and muscling (WM) at weaning

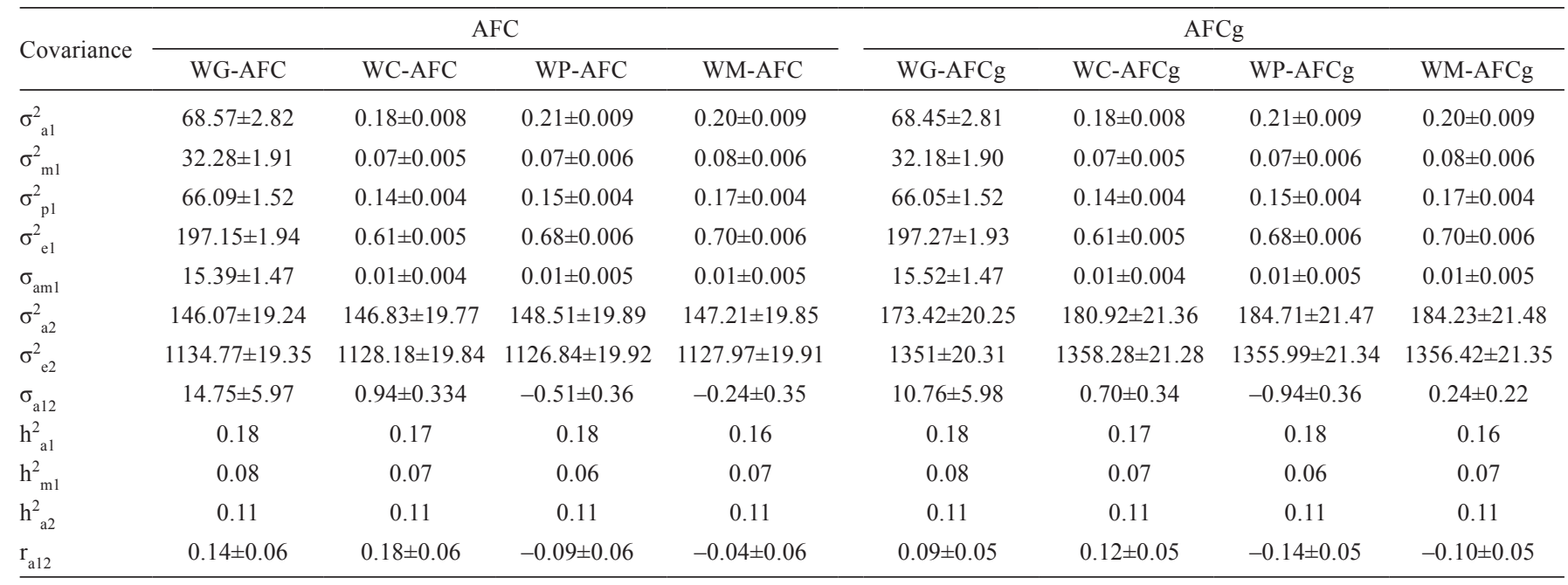

$\sigma_{\mathrm{a} 1}^{2}$ - variance of the direct effect of the first trait; $\sigma_{\mathrm{m} 1}^{2}$ - variance of the maternal effect of the first trait; $\sigma_{\mathrm{p} 1}^{2}$ - variance of the maternal permanent environmental effect on the first trait; $\sigma^{2}$ - residual variance of the first trait; $\sigma_{\text {am } 1}$ - covariance between direct and maternal effects of the first trait; $\sigma^{2}$ - variance of the direct effect of the second trait $(\mathrm{AFC}) ; \sigma_{\mathrm{e} 2}^{2}$ - residual variance of the second trait (AFC); $\sigma_{\mathrm{a} 12}$ - covariance between the direct effect of the first trait and the direct effect of the second trait; $\mathrm{h}^{2}{ }_{\mathrm{a} 1}$ - heritability of the direct effect of the first trait (weight gain, conformation, precocity, or muscling); $\mathrm{h}_{\mathrm{m} 1}^{2}$ - heritability of the maternal effect of the first trait (weight gain, conformation, precocity, or muscling); $\mathrm{h}_{\mathrm{a} 2}^{2}$ - heritability of the direct effect of the second trait (AFC or AFCg); $\mathrm{r}_{\mathrm{a} 12}$ - genetic correlation between both traits. 
Direct heritability estimates of the visual scores at 18 months were $0.27,0.29$, and 0.27 for conformation, precocity, and muscling scores, respectively.

The analyses demonstrate, in general, weak and negative correlations between production traits and $\mathrm{AFC}$, ranging from almost zero ( -0.01 for post-weaning gain - AFC) to low $(-0.13 \pm 0.03$ for precocity at 18 months - AFC), except for the correlations between weight gain and conformation at weaning (0.14 and 0.18 , respectively), which were positive.

The estimated direct heritability for the final index was almost $1(0.98)$ and genetic correlations between final index and AFC or AFCg were -0.08 and -0.09 , respectively (Table 4).

\section{Discussion}

Means for AFC and AFCg were close to the value observed by Dias et al. (2004) of 34.44 months. Higher values were reported in Nelore heifers (Azevêdo et al., 2006). The lower AFC values obtained in the present study relative to those reported in literature resulted from the strong genetic selection imposed on the studied herds for this trait, as well as to the management practice of sexually challenging the heifers between 13 and 16 months of age. It is known that AFC expression is also limited by breeding season, considering both the season when the heifer was born and its first breeding season. Heifers born late in the breeding season are younger and

Table 3 - Covariance component estimates and genetic parameters obtained with the bi-character analyses of the traits age at first calving (AFC) and age at first calving with the inclusion of heifers that did not calve (AFCg) with weight gain (YG), conformation (YC), precocity (YP), and muscling (YM) at eighteen months of age

\begin{tabular}{|c|c|c|c|c|c|c|c|c|}
\hline \multirow{2}{*}{ Covariance } & \multicolumn{4}{|c|}{$\mathrm{AFC}$} & \multicolumn{4}{|c|}{$\mathrm{AFCg}$} \\
\hline & YG-AFC & YC-AFC & YP-AFC & YM-AFC & YG-AFCg & YC-AFCg & YP-AFCg & YM-AFCg \\
\hline$\sigma_{a 1}^{2}$ & $69.23 \pm 2.27$ & $0.25 \pm 0.005$ & $0.29 \pm 0.006$ & $0.27 \pm 0.006$ & $69.27 \pm 2.27$ & $0.25 \pm 0.005$ & $0.29 \pm 0.006$ & $0.27 \pm 0.006$ \\
\hline$\sigma_{\mathrm{a} 2}^{2}$ & $166.26 \pm 21.06$ & $164.82 \pm 20.87$ & $165.57 \pm 20.81$ & $166.16 \pm 20.84$ & $206.58 \pm 23.02$ & $203.45 \pm 22.37$ & $201.16 \pm 22.22$ & $202.92 \pm 22.28$ \\
\hline$\sigma_{\mathrm{e} 2}^{2}$ & $1102.29 \pm 21.06$ & $1114.19 \pm 20.61$ & $1113.86 \pm 20.55$ & $1113.35 \pm 20.57$ & $1290.99 \pm 22.48$ & $1331.18 \pm 21.92$ & $1333.42 \pm 21.82$ & $1331.91 \pm 21.85$ \\
\hline $\mathrm{h}_{\mathrm{a} 2}^{2}$ & 0.13 & 0.12 & 0.12 & 0.12 & 0.13 & 0.13 & 0.13 & 0.13 \\
\hline$r_{a 12}$ & $-0.01 \pm 0.04$ & $-0.04 \pm 0.04$ & $-0.13 \pm 0.03$ & $-0.10 \pm 0.04$ & $-0.04 \pm 0.04$ & $-0.05 \pm 0.03$ & $-0.15 \pm 0.03$ & $-0.13 \pm 0.03$ \\
\hline
\end{tabular}

$\sigma^{2}{ }_{a 1}$ - variance of the direct effect of the first trait; $\sigma^{2}{ }^{2}$ - variance of the maternal effect of the first trait; $\sigma^{2}{ }_{22}$ - variance of the direct effect on the second trait (AFC); $\sigma^{2}{ }_{\mathrm{e} 2}$ - residual variance of the second trait (AFC); $\sigma_{\mathrm{a} 12}$ - covariance between the direct effect of the first trait and the direct effect of the second trait; $\mathrm{h}^{2}{ }_{\mathrm{a} 1}-\mathrm{heritability}$ of the direct effect of the firs trait (weight gain, conformation, precocity, or muscling) $; \mathrm{h}^{2}{ }_{\mathrm{a} 2}$ - heritability of the direct effect of the second trait (AFC or AFCg); $\mathrm{r}_{\mathrm{a} 2}-\mathrm{genetic}$ correlation between both traits.

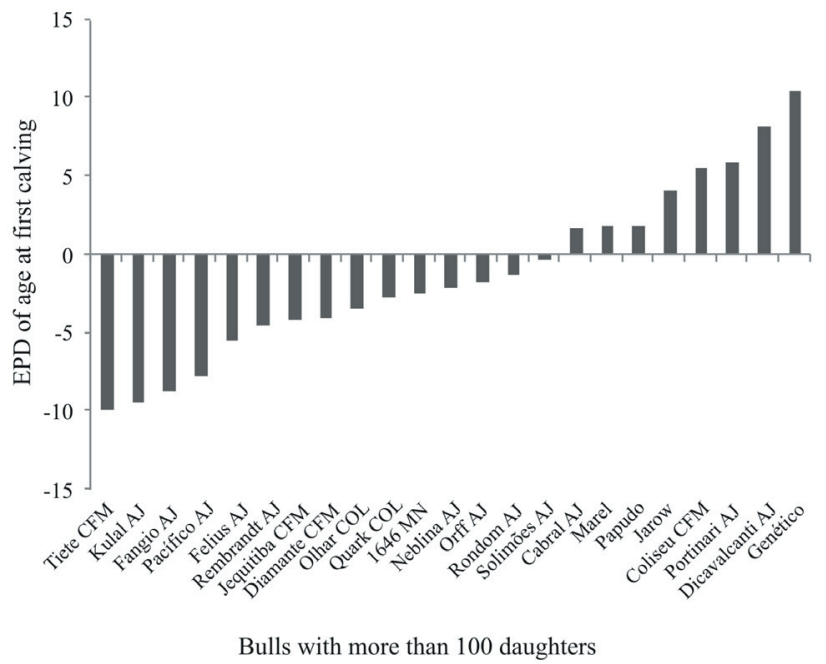

Figure 2 - Expected progeny differences (EPD) of age at first calving (in days) for bulls with more than 100 daughters.
Table 4 - Covariance component estimates and genetic parameters obtained with the bi-character analyses of the traits age at first calving (AFC) and age at first calving with the inclusion of heifers that did not calve (AFCg) with final index

\begin{tabular}{lcc}
\hline Covariance & Final index-AFC & Final index-AFCg \\
\hline$\sigma^{2}{ }_{\mathrm{a} 1}$ & $22.47 \pm 0.15$ & $22.47 \pm 0.15$ \\
$\sigma^{2}{ }_{\mathrm{e} 1}$ & $0.32 \pm 0.06$ & $0.32 \pm 0.06$ \\
$\sigma^{2}{ }_{\mathrm{a} 2}$ & $169.00 \pm 21.23$ & $193.14 \pm 22.12$ \\
$\sigma^{2}{ }_{\mathrm{e} 2}$ & $1112.71 \pm 20.92$ & $1332.25 \pm 21.82$ \\
$\mathrm{~h}^{2}{ }_{\mathrm{a} 1}$ & 0.98 & 0.98 \\
$\mathrm{~h}^{2}{ }_{\mathrm{a} 2}$ & 0.12 & 0.12 \\
$\mathrm{r}_{\mathrm{a} 12}$ & $-0.08 \pm 0.02$ & $-0.09 \pm 0.02$ \\
\hline
\end{tabular}

$\sigma_{\mathrm{a} 1}^{2}$ - variance of the direct effect of final index; $\sigma_{\mathrm{el}}^{2}$ - variance of the residual effect of final index; $\sigma^{2}{ }_{\mathrm{a} 2}$ - variance of the direct effect on the second trait (AFC or AFCg); $\sigma^{2}{ }_{\mathrm{e} 2}$ - residual variance of the second trait (AFC or $\left.\mathrm{AFCg}\right) ; \mathrm{h}^{2}{ }_{\mathrm{a} 1}$ - heritability of the direct effect of final index; $\mathrm{h}^{2}{ }_{\mathrm{a} 2}$ - heritability of the direct effect of the second trait (AFC or AFCg); $r_{\mathrm{a} 12}$ - genetic correlation between both traits. 
may calve earlier than those born early in the same season (Bormann and Wilson, 2010).

The low values for AFC and AFCg heritabilities are consistent with those reported in literature for Nelore, ranging between $0.09 \pm 0.03$ (Dias et al., 2004) and $0.21 \pm 0.05$ (Azevêdo et al., 2006). The similar values obtained for AFC and AFCg heritability estimates may be explained by the high heifer pregnancy rate in the studied herds, which number of non-pregnant females represented $19.58 \%$. This probably happened because farmers do not report all heifers exposed to breeding, but only those that got pregnant and calved.

Values found for direct heritability for visual score traits were consistent with those obtained by Forni et al. (2007), who obtained heritability estimates of $0.12,0.15$, and 0.12 for conformation, precocity, and muscling at weaning, respectively in Nelore cattle. Koury Filho et al. (2010), in herds with predominantly Nelore genes in their genetic composition, found heritability estimates of visual scores of $0.13,0.25$, and 0.23 for conformation, precocity, and muscling, respectively, at weaning.

The highest heritability values found at 18 months of age show that maternal environmental effects and maternal genetic effects were in some way important in the estimation of heritability at weaning. Koury Filho et al. (2010) observed that the inclusion of the maternal environmental effect is important in the evaluation of traits up to weaning, even though the maternal genetic effect is considered. These authors also found higher heritability estimates for data at 18 months than at weaning.

Forni et al. (2007) obtained lower maternal heritability estimates than those found in this study for visual scores at weaning ( 0.04 for conformation, 0.03 for precocity, and 0.05 for muscling) in Nelore cattle. Values for direct heritability estimates for conformation, precocity, and muscling were similar to those obtained by several researchers (Cardoso et al., 2004; Koury Filho et al., 2009).

The results for the genetic correlations were consistent with literature, in which the genetic association between growth and reproductive traits are usually reported as close to zero or slightly negative (Mercadante et al., 2000; Pereira et al., 2001). The genetic correlations between weight gain from birth to weaning and conformation at weaning with AFC ( 0.14 and 0.18 , respectively) indicate that the higher the weight gain at this stage, and the better the conformation, the greater the age at first calving. On the other hand, AFC correlations with precocity and muscling at weaning were small, showing that they are almost genetically independent. The negative signs in these two correlations indicate that the greater the muscling, and the greater the precocity, the lower the age at the first parturition. These results suggest that these traits, which are subjective and related to finishing, should be used with caution when the intention is to correlate them with sexual precocity.

The positive associations between $\mathrm{AFC}$ and weight gain from birth to weaning and between $\mathrm{AFC}$ and conformation at weaning may also be explained by the fact that weight gain is genetically determined and associated to mature size. Selection for weaning and yearling weights of replacement heifers result in cows with bigger mature sizes (Klosterman, 1972), which may negatively affect female fertility (LunaNevarez et al., 2010).

However, Mercadante et al. (2003), in a study with Nelore cattle, concluded that the selection for body weight results in significant body weight responses in yearlings and older cattle, but the trait days to calving is not affected. Our results partially agree with theirs, once the correlation close to zero between AFC and weight gain at 18 months of age ( -0.01 and -0.04 , respectively for AFC and $\mathrm{AFCg})$ indicates they are genetically independent from each other.

At eighteen months of age, the correlations between precocity and muscling with $\mathrm{AFC}$ and $\mathrm{AFCg}$ remained low and negative, despite a small numerical increase. On the other hand, the correlation with conformation decreased, being close to zero and negative.

The inclusion of heifers that did not calve in the analysis of the data of 18 months increased correlation values up to $5 \%$. Supporting the idea that heifers that did not conceive after the breeding season would have worse genetic merit for this trait and removing them from the analysis may exclude relevant information on genetic differences among herds (Meyer et al., 1990).

The genetic correlations between $\mathrm{AFC}$ and final index (Table 4) were low $(-0.08$ and -0.09 , respectively for $\mathrm{AFC}$ and $\mathrm{AFCg}$ ). Despite this low genetic correlation, it is favorable, as the increase in the final index tends to be coupled with a reduction in AFC. The negative correlation is probably due to the traits precocity and muscling, which are part of final index and are negatively correlated with it. The heritability estimates close to 1.00 found in the present study for final index are due to the fact that this index is based on standardized expected progeny differences, which contain the sum of the additive genetic effects after the non-genetic effects that influence the phenotype to be removed.

\section{Conclusions}

The heritability estimates obtained in the present study show that it is possible to achieve genetic gains by selection 
of all the analyzed traits. However, higher response to selection is expected when selection is practiced at eighteen months of age than at weaning. Apparently, selection for traits related to carcass characteristics and production, such as visual scores and selection index including these traits, do not affect, or minimally affect, the age at first calving and vice versa.

\section{Acknowledgments}

We thank the DeltaGen for providing the database presented in this manuscript. We also acknowledge the funding from the Conselho Nacional de Desenvolvimento Científico e Tecnológico (Project CNPq/PDJ no. 150458/ 2015).

\section{References}

Azevêdo, D. M. M. R.; Martins Filho, R; Lôbo, R. N. B.; Malhado, C. H. M.; Lôbo, R. B.; Moura, A. A. A. and Pimenta Filho, E. C. 2006. Desempenho reprodutivo de vacas Nelore no Norte e Nordeste do Brasil. Revista Brasileira de Zootecnia 35:988-996. doi: 10.1590/S1516-35982006000400008.

Biffani, S.; Martins Filho, R. and Lucifero, M. 2000. Características reprodutivas de fêmeas da raça Nelore criadas na região Nordeste do Brasil. In: Anais da $37^{\text {a }}$ Reunião Anual da Sociedade Brasileira de Zootecnia, Viçosa, MG.

Bormann, J. M. and Wilson, D. E. 2010. Calving day and age at first calving in Angus heifers. Journal of Animal Science 88:1947-1956.

Cardoso, F. F.; Cardellino, R. A. and Campos, L. T. 2004. Componentes de (co)variância e parâmetros genéticos de caracteres pósdesmama em bovinos da raça Angus. Revista Brasileira de Zootecnia 33:313-319. doi: 10.1590/S1516-35982004000200006

Dias, L. T.; El Faro, L. and Albuquerque, L. G. 2004. Estimativas de herdabilidade para idade ao primeiro parto de novilhas da raça Nelore. Revista Brasileira de Zootecnia 33:97-102. doi: 10.1590/ S1516-35982004000100013.

Forni, S.; Federici, J. F. and Albuquerque, L. G. 2007. Tendências genéticas para escores visuais de conformação, precocidade e musculatura à desmama de bovinos Nelore. Revista Brasileira de Zootecnia 36:572-577. doi: 10.1590/S1516-35982007000300008

Hazel, L. N.; Dickerson, G. E. and Freeman, A. E. 1994. The selection index - Then, now, and for the future. Journal of Animal Science 77:3236-3251.
Klosterman, E. W. 1972. Beef cattle size for maximum efficiency. Journal of Animal Science 34:875-80.

Koury Filho, W.; Albuquerque, L. G.; Alencar, M. M.; Forni, S.; Silva, J. A. V. and Lôbo, R. B. 2009. Estimativas de herdabilidade e correlações para escores visuais, peso e altura ao sobreano em rebanhos da raça Nelore. Revista Brasileira de Zootecnia 38:23622367. doi: 10.1590/S1516-35982009001200010

Koury Filho, W.; Albuquerque, L. G.; Forni, S.; Silva, J. A. V.; Yokoo, M. J. and Alencar, M. M. 2010. Estimativas de parâmetros genéticos para os escores visuais e suas associações com peso corporal em bovinos de corte. Revista Brasileira de Zootecnia 39:1015-1022. doi: 10.1590/S1516-35982010000500011

Luna-Nevarez, P.; Bailey, D. W.; Bailey, C. C.; Van Leeuwen, D. M.; Enns, R. M.; Silver, G. A.; Deatley, K. L. and Thomas, M. G. 2010. Growth characteristics, reproductive performance, and avaluation of their associative relationships in Brangus cattle managed in a Chihuahuan Desert production system. Journal of Animal Science 88:1891-1904. doi: 10.2527/jas.2009-2541

Madsen, P.; Jensen, J.; Labouriau, R.; Christensen, O. F. and sahana, G. 2006. A Package for analyzing multivariate mixed models. In: Anais do $8^{\circ}$ World Congress on Genetics Applied To Livestock Production. Belo Horizonte.

Mercadante, M. E. Z.; Lôbo, R. B. and Oliveira, H. N. 2000. Estimativas de (co)variâncias entre características de reprodução e de crescimento em fêmeas de um rebanho Nelore. Revista Brasileira de Zootecnia 29:997-1004. doi: 10.1590/S151635982000000400008

Mercadante, M. E. Z.; Packer, I. U.; Razook, A. G.; Cyrillo, J. N. and Figueiredo, L. A. 2003. Direct and correlated responses to selection for yearling weight on reproductive performance of Nelore cows. Journal of Animal Science 81:376-384.

Meyer, K.; Hammond, P. F.; Parnell, M. J.; Mackinnon, M. J. and Sivarajasingam, S. 1990. Estimates of heritability and repeatability for reproductive traits in Australian beef cattle. Livestock Production Science 25:15-30. doi: 10.1016/0301-6226(90)90038-8

Nunez-Dominguez, R.; Cundiff, L. V. and Dickerson, G. E. 1991. Lifetime production of beef heifers calving first at two vs three years of age. Journal of Animal Science 69:3467-3479.

Pereira, E.; Eler, J. P. and Ferraz, J. B. S. 2001. Análise genética de algumas características reprodutivas e suas relações com o desempenho ponderal na raça Nelore. Arquivo Brasileiro de Medicina Veterinária e Zootecnia 53:720-727. doi: 10.1590/ S0102-09352001000600019.

Schaeffer, L. R. 2011. Multiple traits. Animal models - Course notes. University of Guelph, p.14. Available at: <http://www.aps. uoguelph.ca/ lrs/ABModels/ NOTES/ multiple.pdf > . Accessed on: Feb. 8, 2011.

Severo, J. L. P. 1994. Manejo e controle de produção para a implantação de um programa de melhoramento genético de bovinos de corte. p.80. In: Bovinos de corte: Seleção e cruzamento. GenSys Consultores Associados S/C Ltda, Porto Alegre. 